Hill and Upland Livestock Production

Occasional Publication No. 10-British Society of Animal Production 1985

edited by T. J. Maxwell and R. G. Gunn

\title{
THE EFFECT OF FECUNDIN UPON THE REPRODUCTIVE PERFORMANCE OF EWES ON COMMERCIAL FARMS IN SOUTH-WEST SCOTLAND - A PRELIMINARY COMMUNICATION
}

\author{
D. N. LOGUE*, I. A. DICKSON $\dagger$, A. WATERHOUSE $\dagger$ and T. H. McCLELLAND $\dagger$ \\ West of Scotland Agricultural College, * Auchincruive, Ayr, and $\dagger$ Pathfoot Building, University of Stirling, Stirling \\ FK9 4LA
}

$\mathbf{T}$

The use of the immunogen ovandrotone-albumin (Fecundin*) has been reported extensively from Australia and New Zealand but field results from the UK are still comparatively small in number (Harding, Hardy and Joby, 1984). This report details the preliminary findings of some investigations conducted by the West of Scotland Agricultural College (WSAC).

Ten farms in the south-west of Scotland, running the traditional ewes of the area - Greyface, Scotch Halfbred, Blackface, South and North Country Cheviot and Texel $\times$ Blackface, were selected for field trials.

On each farm, approximately 100 ewes were divided into two groups of $\mathbf{5 0}$ on the basis of age and condition score. One group was treated twice with Fecundin at between $48-60$ and $20-24$ days before ram introduction. All the ewes were condition scored and weighed at both these gathers, again before tupping and in midpregnancy. A further trial was conducted on the WSAC hill farm at Kirkton-Auchtertyre, where 170 Blackface ewes were split by age, weight and condition score into four groups to give a $2 \times 2$ experimental design testing Fecundin with or without Veramix $\dagger$ progestagen sponges. The treatment was similar to the above.

The effect of Fecundin treatment upon subsequent

TABLE 1

Effect of Fecundin* treatment upon ewe performance: field trials

\begin{tabular}{|c|c|c|c|c|c|c|c|c|c|}
\hline \multirow[b]{2}{*}{ 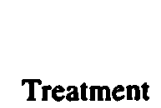 } & \multirow{2}{*}{$\begin{array}{l}\text { Total } \\
\text { no. } \\
\text { ewes }\end{array}$} & \multirow{2}{*}{$\begin{array}{l}\text { No. with } \\
\text { reliable } \\
\text { records } \neq\end{array}$} & \multirow{2}{*}{$\begin{array}{l}\text { No. dead } \\
\text { or aborted }\end{array}$} & \multicolumn{5}{|c|}{ Distribution of ewes by litter size } & \multirow{2}{*}{$\begin{array}{c}\% \\
\text { Lamb } \\
\text { drop }\end{array}$} \\
\hline & & & & 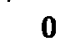 & 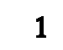 & 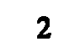 & & 4 & \\
\hline & $\begin{array}{l}455 \\
450\end{array}$ & 409 & $\begin{array}{l}1 \\
6\end{array}$ & 4 & 113 & & 63 & 1 & \\
\hline
\end{tabular}

‡ Still some lambing data unavailable.

- \% Lamb drop $=$ total number lambs born/100 ewes to the tup.

- Fecundin - Coopers/Glaxo.

TABLE 2

Effect of Fecundin* and/or Veramixt progestagen sponge treatment on ewe performance (Kirkton Trial)

\begin{tabular}{|c|c|c|c|c|c|c|c|c|}
\hline \multirow[b]{2}{*}{ Treatment } & \multirow{2}{*}{$\begin{array}{c}\text { Total no. } \\
\text { ewes } \\
\text { treated }\end{array}$} & \multirow{2}{*}{$\begin{array}{l}\text { No. with } \\
\text { reliable } \\
\text { records }\end{array}$} & \multirow{2}{*}{$\begin{array}{l}\text { No. dead } \\
\text { or aborted }\end{array}$} & \multicolumn{4}{|c|}{ Distribution of ewes by litter size } & \multirow{2}{*}{$\begin{array}{c}\% \\
\text { Lamb } \\
\text { drope }\end{array}$} \\
\hline & & & & $\mathbf{0}$ & 1 & 2 & 3 & \\
\hline cundin \& prog. & 43 & 41 & 2 & 1 & 12 & 20 & 6 & 171 \\
\hline ecundin & 42 & 42 & - & 2 & 14 & 19 & 7 & 174 \\
\hline Progestagen & 43 & 43 & 2 & 4 & 17 & 20 & - & 133 \\
\hline Control & 42 & 42 & - & 2 & 18 & 22 & - & 148 \\
\hline
\end{tabular}

- $\%$ Lamb drop $=$ total number lambs born/100 ewes tupped.

- Fecundin - Coopers/Glaxo.

+ Veramix - Upjohn. 
ewe performance on 9 of the 10 collaborating farms is shown in Table 1 . While these figures are incomplete, they are still significant, furthermore, the overall increase in the total number of lambs born/100 ewes tupped (percentage lamb drop) is very similar to that seen in the Kirkton results $(+31 \%$ cf $+32 \%)$, the latter are also significant (see Table 2). However, the variation between individual farms was large, $+13 \%$ to $+67 \%$. While the interaction of breed, percentage lamb drop and mean flock pre-tupping condition score make firm conclusions impossible, at least at present, it would appear that breed type is relatively unimportant and that for the most consistent response a condition score between 2.5 and 3.0 and a "baseline" percentage lamb drop of less than 180 is advisable.

Good records of lamb survival in the first $24 \mathrm{~h}$ have been obtained from 7 farms and to date these show no evidence of increased losses (according to litter size) in the treated group. Moreover, lambs were weighed on two of the farms (and also at Kirkton) and no significant difference between the groups was noted.

One further consistent finding was that the treated ewes were tupped later overall than the controls and tended to have a greater lambing spread. This was particularly noticeable on the farm with the highest "baseline" percentage lamb drop. This effect was also noted in both progestagen and non-progestagen treated groups at Kirkton. A similar effect was reported in some Irish trials (Hanrahan and Quirke, 1985).

\section{ACKNOWLEDGEMENTS}

We gratefully acknowledge the many members of the WSAC staff who contributed to these results, the co-operating farmers and Coopers/Glaxo and Upjohn for their assistance.

\section{REFERENCES}

HARDing, R. B., HARDY, P. R. D. and Joby, R. 1984. Increasing lambing rates with ovandrotonealbumin. Vet. Rec. 115: 601.

Hanrahan, J. P. and Quirke, J. F. 1985. Effects of immunisation against androstenedione on the reproductive performance of ewes. Anim. Prod. 40: 524 (Abstr.).

\footnotetext{
- Fecundin - Coopers/Glaxo.

† Veramix - Upjohn.
} 